\title{
Cold-pressed minke whale oil reduces circulating LDL/VLDL-cholesterol, lipid oxidation and atherogenesis in apolipoprotein E-deficient mice fed a Western-type diet for 13 weeks
}

Mari Johannessen Walquist ${ }^{*}$, Svein Kristian Stormo ${ }^{2}$, Bjarne Østerud ${ }^{3}$, Edel O. Elvevoll ${ }^{1}$ and Karl-Erik Eilertsen ${ }^{1}$

\begin{abstract}
Background: Long-chain n3-polyunsaturated fatty acids (LC n3-PUFA) are well known for their anti-inflammatory activity and their impact on cardiovascular disease. Cold-pressed whale oil (CWO) has half the amount of LC n3-PUFA compared to cod liver oil (CLO). Still, there has been observed more pronounced beneficial effects on cardiovascular disease markers from intake of CWO compared to intake of CLO in human intervention studies. Extracts from CWO deprived of fatty acids have also been shown to display antioxidative and anti-inflammatory effects in vitro. The aim of this study was to investigate whether intake of a high-fat Western-type diet (WD) supplemented with CWO would prevent the development of atherosclerotic lesions in apolipoprotein E-deficient $\left(\mathrm{ApoE}^{-/-}\right)$mice.

Methods: Seventy female ApoE ${ }^{-/}$mice were fed a WD containing 1\% CWO, CLO or corn oil (CO). Atherosclerotic lesion formation, body and tissue weights, hepatic gene expression together with serum levels of LDL/NLDLcholesterol, ox-LDL, total antioxidant status and various serum cardiovascular disease/proinflammatory markers were evaluated. Statistical analyses were performed using SPSS, and Shapiro-Wilk's test was performed to determine the distribution of the variables. Statistical difference was assessed using One-Way ANOVA with Tukeys' post hoc test or Kruskal-Wallis test. The hepatic relative gene expression was analysed with REST 2009 (V2.0.13).
\end{abstract}

Results: Mice fed CWO had less atherosclerotic lesions in the aortic arch compared to mice fed CO. Levels of LDL/ VLDL-cholesterol and ox-LDL-cholesterol were also markedly reduced whereas total antioxidant levels were enhanced in mice fed CWO compared to CO-fed mice. In addition, CWO-fed mice gained less weight and several hepatic genes involved in the cholesterol metabolism were up-regulated compared to CO-fed mice.

Conclusion: In the present study mice fed a WD supplemented with 1\% CWO had reduced formation of atherosclerotic lesions in the aortic arch, reduced serum LDLNLDL-cholesterol and ox-LDL-cholesterol, increased serum total antioxidant status and reduced body weight compared to mice fed a WD supplemented with 1\% CO.

Keywords: Atherosclerosis, Plaque, Lesions, Balaenoptera acutorostrata, Whale oil, Blubber, Gene expression, LDLcholesterol, VLDL-cholesterol

\footnotetext{
*Correspondence: mari.walquist@uit.no

${ }^{1}$ Norwegian College of Fishery Science, Faculty of Biosciences, Fisheries and

Economics, UiT - The Arctic University of Norway, 9037 Tromsø, Norway

Full list of author information is available at the end of the article
}

(c) The Author(s). 2018 Open Access This article is distributed under the terms of the Creative Commons Attribution 4.0 International License (http://creativecommons.org/licenses/by/4.0/), which permits unrestricted use, distribution, and reproduction in any medium, provided you give appropriate credit to the original author(s) and the source, provide a link to the Creative Commons license, and indicate if changes were made. The Creative Commons Public Domain Dedication waiver (http://creativecommons.org/publicdomain/zero/1.0/) applies to the data made available in this article, unless otherwise stated. 


\section{Background}

Atherosclerosis is characterized by arterial lipid lesions in the intima of large arteries and the illness may be silent or symptomless for decades. Yet, atherosclerosis is the major underlying cause of several other cardiovascular diseases (CVD) such as unstable angina, myocardial infarction and stroke. Years of lipid accumulation in the vascular wall cause plaque formation and narrowing of the lumen. Plaque rupture may eventually lead to acute atherothrombosis preventing adequate blood flow to lung, heart and brain tissue $[1,2]$. The link between atherosclerosis and inflammation has been comprehensively elucidated [3-7], and several cytokines and chemokines are key contributors in atherosclerotic progression [8-11]. The antiinflammatory effects of long-chain n3-polyunsaturated fatty acids (LC n3-PUFA) are well known. Especially eicosapentaenoic acid (EPA) and docosahexaenoic acid (DHA) and how they contribute to mitigate atherosclerotic progression in coronary patients [12-17]. Oily fish is a good dietary source of EPA and DHA. Fish also contain other constituents such as proteins, amino acids, peptides and bioactive compounds that may contribute to the beneficial effects observed after fish intake [18-20].

The common minke whale (Balaenoptera acutorostrata) feeds on crustaceans and pelagic fish in the North Atlantic [21], and their thick layer of blubber is vital for thermal insulation, buoyancy and energy storage [22]. Blubber has been an important part of the diet to indigenous people in Arctic and Subarctic regions for centuries. Two decades ago, cold-pressed whale oil (CWO) and cod liver oil (CLO) were given as dietary supplements to healthy individuals as part of a larger study $[23,24]$. The results indicated that the CWO group had beneficial effect on CVD markers and improved inflammatory effect, also when compared to the CLO group. The fatty acid (FA) composition of CWO and CLO differ in the amount of LC n3-PUFA. Whale blubber has $10.3 \%$ LC n3-PUFA, including 3.3\% EPA, 1.7\% docosapentaenoic acids (DPA) and 4.7\% DHA while CLO has $25.1 \%$ LC n3-PUFA, including 9.5\% EPA, 1\% DPA and 13.5\% DHA in CLO [24]. Recently, we demonstrated in an in vitro study with CWO deprived of fatty acids, that CWO contained extractable antioxidants and had anti-inflammatory activities associated with hitherto unidentified compound(s) [25].

In the present study, we investigated whether intake of a high-fat Western-type diet (WD) supplemented with CWO or refined whale oil (RWO) in combination with extracts from whale blubber would prevent the development of atherosclerotic lesions in Apolipoprotein E-deficient $\left(\mathrm{ApoE}^{-/-}\right)$mice.

\section{Methods}

Experimental animals and housing

Seventy-two pathogen-free female $\mathrm{ApoE}^{-1-}$-mice (B6. 129P2-Apoe $e^{t m 1}$ Unc N11) were purchased from Taconic
(Taconic M\&B, Ry, Denmark). After arrival at the local animal facility all mice were earmarked and randomly allocated into 6 groups $(n=12)$ with equal numbers of cages per intervention ( $n=4$ cages/diet). Due to weight loss during the one-week acclimatization, two mice were excluded ( $n=11$ in the RWO-I and CWO groups). At the start of the experiment, the mice were 6 weeks of age with a body weight range of 16 to $21 \mathrm{~g}$. Mice provided with water and pelleted feed ad libitum for 13 weeks were kept in ventilated cages placed in the same room in a conventional laboratory animal unit. The temperature and relative humidity were $21{ }^{\circ} \mathrm{C}$ and $55 \%$ on a 12-h day/night cycle (light: 0600 to $1800 \mathrm{~h}$ ). The cages and bedding were changed once a week. At the end of the study all mice were feed-deprived for $3 \mathrm{~h}$ prior to euthanizing by carbon dioxide inhalation. Blood was drawn by cardiac puncture and serum was prepared and frozen at $-80^{\circ} \mathrm{C}$. Cardiac, hepatic, renal, splenic and adipose tissues were dissected out, weighed, snap frozen and stored at $-80{ }^{\circ} \mathrm{C}$.

\section{Preparation of dietary oils}

Freshly frozen blubber from common minke whale was provided by Ellingsen Seafood AS (Skrova, Norway). The blubber was ground once before centrifugation at $<2000 \times g$ $\left(<40{ }^{\circ} \mathrm{C}\right)$. After centrifugation the oily top-layer, hereafter referred to as CWO in this study, was collected and $250 \mathrm{~g}$ CWO was extracted in $800 \mathrm{ml}$ methanol/dichloromethane (1:1). After phase separation, most of the lipids (oil) was in the fraction containing dichloromethane. The better part of the dichloromethane was removed by a rotary evaporator and the remaining solvent was removed during nitrogen flushing for $48 \mathrm{~h}$. After extraction of the CWO, the oil that was left is referred to as RWO. For the methanol phase, containing more polar compounds extracted from CWO, residual dichloromethane and oil were removed with a rotary evaporator followed by $3 \times 200 \mathrm{ml}$ heptane liquid-liquid extraction. Subsequently, the methanol in this fraction was evaporated to almost dryness and was finally removed by flushing the sample with nitrogen for $48 \mathrm{~h}$ (extract I). The remnant of whale blubber after the initial removal of oil top layer was next extracted according to the same protocol as for CWO. Due to the low level of oil in the cold pressed blubber, refined whale oil was not collected from this dichloromethane fraction. Extract II (whale blubber extract) was also flushed with nitrogen for $48 \mathrm{~h}$ to remove all traces of solvents. Oils and extracts were flushed with nitrogen and stored at $-20{ }^{\circ} \mathrm{C}$ prior to further analyses. Commercial CLO was bought from Orkla Health [26] whereas CO was bulk oil provided by the diet manufacturer.

\section{Experimental diets}

The mice were fed six different high-fat WD (modified from EF D-12079, ssniff Spezialdiäten $\mathrm{GmbH}$ ). The six diets were supplemented with $1 \%$ of six different PUFA-rich 
oils as indicated in Table 1. Diet A was a control diet containing $1 \% \mathrm{CO}$, diet $\mathrm{B}$ contained $1 \%$ commercial CLO [26], diet $\mathrm{C}$ contained $1 \% \mathrm{RWO}$, diet $\mathrm{D}$ contained $1 \%$ RWO-I, diet E contained 1\% RWO-II, and diet F contained 1\% CWO. Apart from the PUFA-source the diets were identical, however to compensate for the higher cholesterol content of CLO compared to the other dietary oils used in this study, a smaller amount of cholesterol was added to the CLO diet $(1.47 \mathrm{~g} / \mathrm{kg}$ vs $1.5 \mathrm{~g} / \mathrm{kg}$ for the rest of the diets, Table 1 ). The experimental diets were stored at $-20{ }^{\circ} \mathrm{C}$ and the feed was changed every week.

\section{Analysis of atherosclerotic plaque}

Immediately after blood drainage, all mice were perfused through the left ventricle with sterile saline $(0.9 \%)$, until no residual blood was apparent in the perfusate (approximate 5 min perfusion). The entire aorta (proximal ascending the aorta to bifurcation of the iliac arteries) was cleaned in situ of periadventitial fat, dissected and fixed in $1 \%$ paraformaldehyde solution. Finally, the aorta was stained by Oil Red $\mathrm{O}$ staining, opened longitudinally and en face-mounted on slides as previously described [27]. After $48 \mathrm{~h}$ rest, the slides were scanned with a highresolution scanner. The lesion areas were evaluated using ImageJ software [28] and the extent of atherosclerosis was reported as the percentage of the total area of a given aortaor an aortic region occupied by atherosclerotic lesions.

\section{Total RNA extraction}

After perfusion of the mice, livers were removed, weighed and frozen in liquid nitrogen before storage at $-80{ }^{\circ} \mathrm{C}$ until extraction. One hundred mg liver tissue was homogenized in $1 \mathrm{ml}$ Trizol (Life Technologies) by bead milling (Precellys 24, Bertin Technologies). The samples were incubated on ice for $30 \mathrm{~min}$ followed by $20 \mathrm{~min}$ centrifugation at $12000 \times \mathrm{g}$ at $4{ }^{\circ} \mathrm{C}$. The samples were precipitated overnight with isopropanol and centrifuged for $21,000 \times \mathrm{g}$ for $30 \mathrm{~min}$ at $4{ }^{\circ} \mathrm{C}$. Pellets were dissolved in RNA storage solutions and RNA was stored at $-80{ }^{\circ} \mathrm{C}$ until further processing. Total RNA concentration was measured using Qubit fluorometer 1.0 (Life Technologies) and the quality tested with Agilent 2100 Bioanalyzer (Agilent Technologies, Inc). The RNA Integrity Factor was of 7.6-9.3 for the samples used.

\section{Reverse transcription and quantitative real-time PCR}

High capacity cDNA Reverse Transcription kit (4,368,813, Applied Biosystems) was used to make 3 triplicates of reverse transcriptase (50 ng total RNA in $20 \mu \mathrm{l}$ ). Quantitative RT-PCR was used to analyse $4 \mu \mathrm{l}$ cDNA per $20 \mu \mathrm{l}$ reaction using TaqMan ${ }^{\oplus}$ Fast Universal PCR Master mix (4,352,042, Applied Biosystems) and with predesigned TaqMan ${ }^{\bullet}$ Gene Expression assays (Additional file 1: Table S1). The 96-wells plates were run at ABI Prism 7500 Fast cycler (Applied Biosystems) using the pre-set amplification profile $\left(95{ }^{\circ} \mathrm{C}\right.$ $20 \mathrm{~s}, 40 \times 95{ }^{\circ} \mathrm{C} 3 \mathrm{~s}$ and $\left.60{ }^{\circ} \mathrm{C} 30 \mathrm{~s}\right)$. The most stably expressed endogenous reference genes, Hypoxanthine-

Table 1 Content of diets $\mathrm{g} / \mathrm{kg}$

\begin{tabular}{|c|c|c|c|c|c|c|}
\hline & $\begin{array}{l}\text { CO } \\
\text { Diet A }\end{array}$ & $\begin{array}{l}\text { CLO } \\
\text { Diet B }\end{array}$ & $\begin{array}{l}\text { RWO } \\
\text { Diet C }\end{array}$ & $\begin{array}{l}\text { RWO-I } \\
\text { Diet D }\end{array}$ & $\begin{array}{l}\text { RWO-II } \\
\text { Diet E }\end{array}$ & $\begin{array}{l}\text { CWO } \\
\text { Diet F }\end{array}$ \\
\hline Corn oil & 10 & & & & & \\
\hline Cod liver oil & & 10 & & & & \\
\hline Refined whale oil & & & 10 & & & \\
\hline Refined whale oil + extract I & & & & 10 & & \\
\hline Refined whale oil + extract II & & & & & 10 & \\
\hline Cold-pressed whale oil & & & & & & 10 \\
\hline Casein & 195 & 195 & 195 & 195 & 195 & 195 \\
\hline Corn starch & 50 & 50 & 50 & 50 & 50 & 50 \\
\hline Maltodextrin. $10 \mathrm{DE}$ & 99.4 & 99.4 & 99.4 & 99.4 & 99.4 & 99.4 \\
\hline Sucrose & 340 & 340 & 340 & 340 & 340 & 340 \\
\hline Celullose powder & 50 & 50 & 50 & 50 & 50 & 50 \\
\hline DL-Methionine & 3 & 3 & 3 & 3 & 3 & 3 \\
\hline AIN mineral premix & 35 & 35 & 35 & 35 & 35 & 35 \\
\hline Vitamin premix & 10 & 10 & 10 & 10 & 10 & 10 \\
\hline Calcium carbonate & 4 & 4 & 4 & 4 & 4 & 4 \\
\hline Choline $\mathrm{Cl}$ & 2 & 2 & 2 & 2 & 2 & 2 \\
\hline Butylated hydroxytoluene & 0.1 & 0.1 & 0.1 & 0.1 & 0.1 & 0.1 \\
\hline Cholesterol & 1.5 & 1.47 & 1.5 & 1.5 & 1.5 & 1.5 \\
\hline Butter fat & 200 & 200 & 200 & 200 & 200 & 200 \\
\hline
\end{tabular}


guanine phosphoribosyltransferase 1 (Hprt1) and TATABox Binding Protein (Tbp), were selected using TaqMan Array Mouse Endogenous Control Assay (4,426,701, Applied Biosystems). The geometric mean of these reference genes was used to normalize gene expressions. Inter plate calibrator and none-template controls were included in all assays.

\section{Serum analyses}

Serum cholesterol, low-density lipoprotein cholesterol and very low-density lipoprotein (LDL/VLDL), glucose, triacylglycerol (TAG), total protein concentrations, uric acid, nonesterified fatty acids (NEFA; D07940, Dialab, Austria) and total antioxidant status (TAS; NX2332 Randox Total Antioxidant Status, Randox Laboratories Ltd., UK) were analysed using conventional enzymatic kits and a MaxMat PLII bioanalyser (MaxMat PL, Montpellier, France). Unless otherwise stated all kits were from MaxMat PL (Montpellier, France). Serum oxidized LDL (Ox-LDL) was quantified in duplicates according to the manufacturers' instruction with a murine ELISA-kit (E90527Mu, USCN Life Science Inc., Texas, US). Serum samples were analysed in duplicates for the following cytokines: interferon gamma (IFNY), interleukin 10 (IL-10), interleukin 1 beta (IL-1ß), interleukin 2 (IL-2), interleukin 5 (IL-5), interleukin 6 (IL-6), keratinocyte chemoattractant growth-regulated oncogene (KC-GRO), and tumour necrosis factor alpha (TNF- $\alpha$ ). These analyses were performed according to the manufacturers' instructions using a MSD Mouse Proinflammatory panel 1 V-Plex kit (MULTIARRAY ${ }^{\ominus}$, Meso Scale Discovery, Gaithersburg, MD).

\section{Statistical analyses}

All of the statistical analyses were performed using IBM SPSS Statistics for Macintosh (Release 22.0.0.0, SPSS, Inc., Chicago, IL, US). The Shapiro-Wilk's test was performed to determine the distribution of the variables and nonnormally distributed variables were log-transformed before statistical analysis. Statistical difference was assessed using One-Way ANOVA with Tukeys' post hoc test or Kruskal-Wallis test. The relative gene expression was analysed with REST 2009 (V2.0.13) [29]. A value of $p<0.05$ was considered statistically significant.

\section{Results}

The general physical health and weight gain appeared normal for all mice except one CO-fed mouse (euthanized due to weight loss) during the 13 weeks with experimental diets. The average daily feed intake $(\mathrm{g} /$ mice) was equal for all of the 6 diet groups (Fig. 1). Still, the mice fed CWO gained less body weight compared to the mice fed $\mathrm{CO}$ (Fig. 2a). Liver weights in mice fed CWO and RWO-II were lower than the liver weights in mice fed CO (Fig. $2 b)$. These significant differences were also present for the

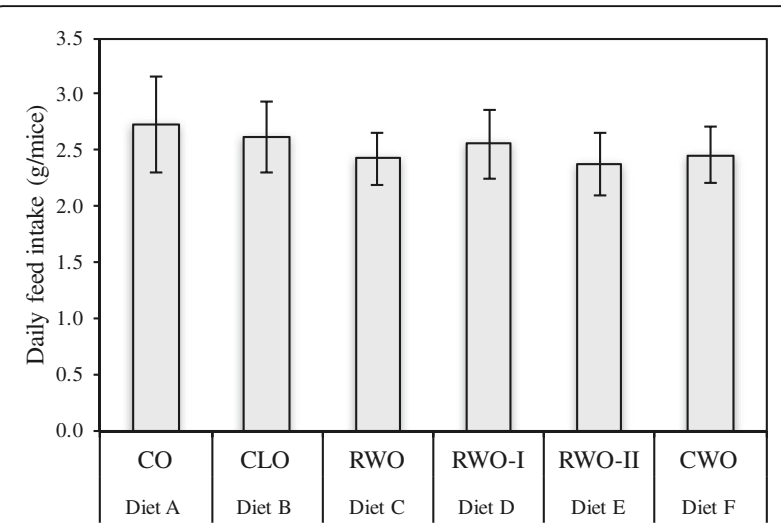

Fig. 1 Average daily feed intake ( $\mathrm{g} /$ mice) of female apolipoprotein E-deficient mice fed high-fat diets supplemented with different oils for 13 weeks. The results are presented as mean \pm SD. CO $(n=11), C L O$ $(n=12)$, RWO $(n=12)$, RWO-I $(n=11)$, RWO-II $(n=12)$, CWO $(n=11)$

relative liver weights. The amount of white adipose tissue was also lower in the mice fed CWO compared to the mice fed $\mathrm{CO}$ (1.44 $\mathrm{g} \pm 0.12$ vs $2.24 \pm 0.2$ respectively), however, not significant $(p=0.078)$. There were no apparent differences in tissue sizes between the groups for heart, kidney or spleen (Table 2). The growth curves for all of the experimental diets are presented in Fig. 2c.

\section{Atherosclerotic lesions}

Five mice were removed from the dataset for atherosclerotic lesion analyses due to methodological artefacts or severe calcification of the abdominal aorta (from the renal arteries down to the iliac bifurcation) despite minimal lesion formation in the aortic arch region. The omitted mice were; three mice fed CLO $(n=9)$, one mouse fed RWO ( $n$ $=11)$ and one mouse fed CWO $(n=10)$. The lesion area in the aortic arch was lower in mice fed CWO compared to the lesion area of the aortic arch in mice fed CO (Fig. 3a). No significant between-group differences were observed in other regions in the aorta (abdominal part, thoracic part or even for the total aorta) (Fig. 3b-d respectively).

\section{Serum antioxidant status, serum LDL/VLDL-cholesterol levels and serum ox-LDL levels}

Serum TAS was higher in mice fed CWO and RWO-II compared to mice fed CO (Fig. 4a). TAS was also higher in mice fed RWO-I, RWO-II and CWO when compared to TAS in mice fed CLO (Fig. 4a). Serum LDL/VLDLcholesterol levels and serum ox-LDL-cholesterol levels were lower in mice fed RWO-I, RWO-II and CWO compared to these levels in mice fed $\mathrm{CO}$ (Fig. $4 \mathrm{~b}$ and c). Total cholesterol (Fig. 4d) and serum triglycerides did not differ between mice fed $\mathrm{CO}$ and the other diet groups; neither did serum glucose or cytokines levels (Table 2). 

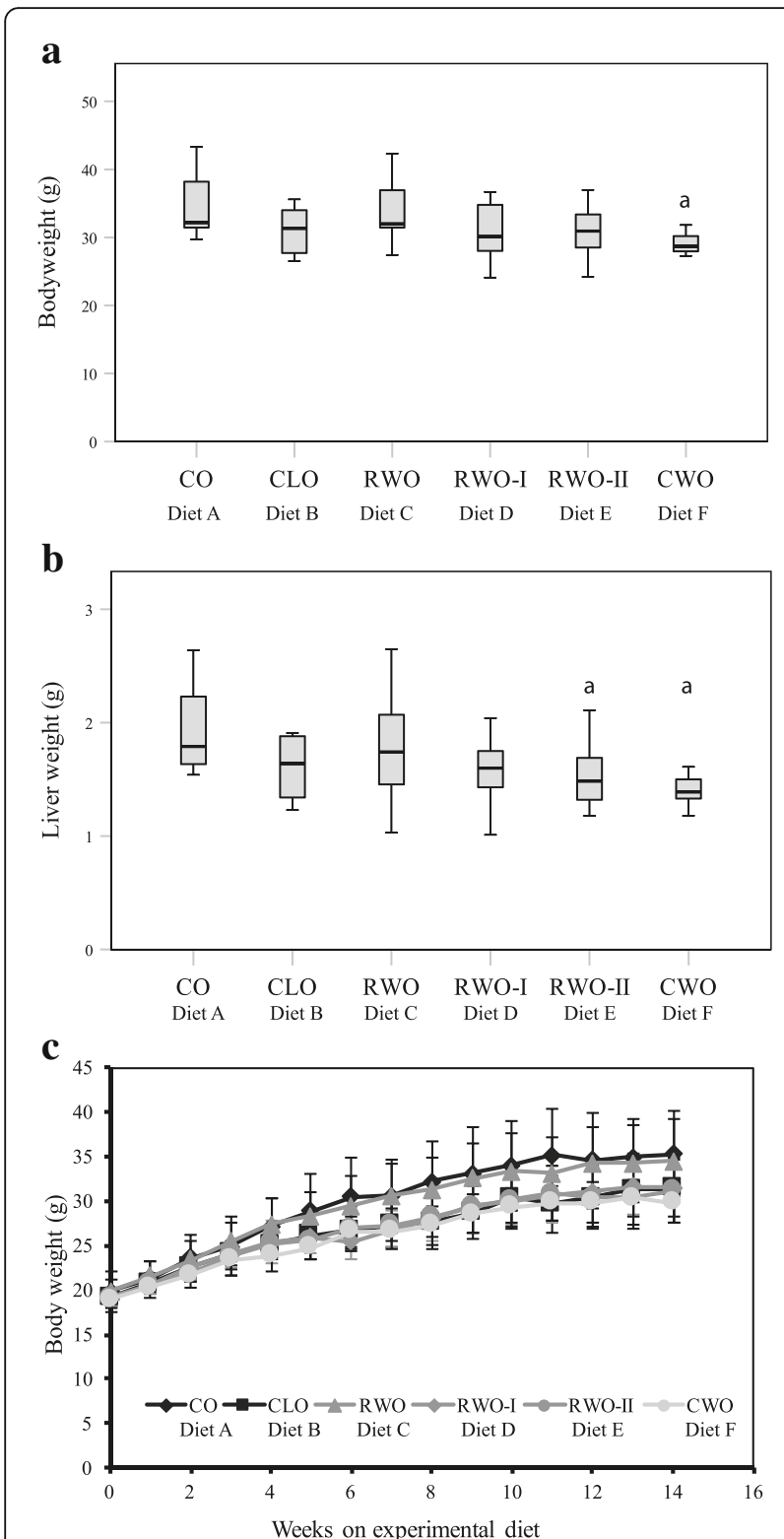

Fig. 2 Final body weight (a), liver weight (b) and growth curves (c) of female apolipoprotein E-deficient mice fed high-fat diets supplemented with difference oils for 13 weeks. Data are presented as box plots representing a 95\% confidence interval (CI) for the median (a and $\mathbf{b}$ ) and as bars representing mean $\pm \mathrm{SD}(\mathbf{c})$. $\mathbf{a}$ denotes significant different from CO (diet A), $p<0.05$. CO $(n=11), C L O(n=9)$, RWO $(n=11)$, RWO-I $(n=11)$, RWO-II $(n=12)$, CWO $(n=10)$

\section{Gene expression}

Hepatic gene expression assessments included genes involved in cholesterol and lipid metabolism, antioxidant defence and in the inflammatory response (Table $3 \mathrm{a}$ and $\mathrm{b}$ ). In mice fed CLO (diet B), expression of the genes ATP binding cassette, sub-family G member 8 (Abcg8) and Scavenger receptor class $B$ member 1 (Sr-b1) was enhanced (1.32 95\% CI [0.64-2.61] and 1.29 95\% CI [0.76-2.29]) whereas Very low density lipoprotein receptor (Vldlr) gene expression was reduced (0.75 95\% CI [0.34-1.59]) compared to mice fed CO (diet A). In mice fed RWO (diet C), Peroxisome proliferator-activated receptor- $\alpha$ (Ppara) gene expression was enhanced (1.41 95\% CI [0.67-2.66]) compared to mice fed CO. In mice fed RWO-I expression of the genes $A b c g 8, S r-b 1$ and Ppara was increased (1.43 95\% CI [0.67-2.05], 1.43 95\% CI [0.78-2.46] and 1.79 [0.77-3. 81] respectively) compared to mice fed $\mathrm{CO}$. The most dramatic changes in gene expression, when compared to mice fed $\mathrm{CO}$, were observed in mice fed RWO-II and where gene expression of Abcg8 (1.40 95\% CI [0.65-2.66]), ATP binding cassette, sub-family $G$ member 5 (Abcg5) (1.28 95\% CI [0.51-2.22]), Cytochrome P450 7A1 (Cyp7a1) (1.95 95\% CI $1.95^{*}$ [0.35-8.92]), 3-hydroxy-3-methyl-glutarylCoenzyme A reductase (Hmgcr) (1.31 [0.62-2.67]), Sr-b1 (1. 26 95\% CI [0.58-2.25]), Ppara (1.39 95\% CI [0.74-2.77]) and Peroxisome proliferator-activated receptor- $\gamma$ (Ppary) (1.26 95\% CI [0.70-2.01]) was increased. In mice fed CWO, gene expression of $A b c g 5$ (1.46 95\% CI [0.59-2.58]), Sr-b1 (1.29 95\% CI [0.66-2.27]) and Ppara (1.39 95\% CI [0.60-3. 09]) was enhanced compared to mice fed CO. Mice from the same group also had elevated gene expression of $A b c g 8$ (1.31 95\% CI [0.62-2.83]), however, not significantly ( $p=0$. 064). Gene expression of Ppary was increased (1.25 95\% CI [0.80-1.83]) in mice fed RWO compared to mice fed CLO. In mice fed RWO-I the gene expression of Ppara (1.57 95\% CI [0.77-3.30]) was increased whereas gene expression of Fatty acid synthase (Fasn) (0.59 95\% CI [0.19-2.66]) was reduced compared to mice fed CLO. Further, when comparing to mice fed CLO, it was observed that mice fed RWOII had increased gene expression of Cyp7a1 (2.23 95\% CI 0. 35-17.1]), Vldlr (1.52 95\% CI [0.76-2.97]) and Ppary (1.37 95\% CI [0.87-2.06]). Finally, in mice fed CWO gene expression of $I L-6$ was reduced $(0.5195 \%$ CI [0.07-3.67]) while gene expression of Uncoupling protein 2 (Upc2) (1.41 95\% CI [0.69-2.94]) was increased compared to mice fed CLO. Expression of all other genes were unaffected by the dietary interventions (Table $3 \mathrm{a}$ and $\mathrm{b}$ ).

\section{Discussion}

The main purpose of this study was to investigate whether dietary consumption of WD supplemented with CWO (diet F) would prevent atherosclerotic development in ApoE ${ }^{-/-}$-mice. Recently, our group demonstrated that extracts from CWO had antioxidant and antiinflammatory activities not related to the content of LC n3-PUFA present [25]. When CWO was given as a dietary supplement to healthy volunteers, beneficial effects on CVD markers and improved anti-inflammatory effect were observed [23, 24]. Herein, WD was supplemented with $1 \%$ of CWO, or $1 \%$ RWO enriched with two different extracts from whale blubber using CO (diet A) and CLO (diet B) as control diets based on previous results [23-25]. 
Table 2 Serum and organ characteristics in female apolipoprotein E-deficient mice fed high-fat Western-type diets supplemented with different oils for 13 weeks

\begin{tabular}{|c|c|c|c|c|c|c|}
\hline & $\begin{array}{l}\text { CO } \\
\text { Diet A }\end{array}$ & $\begin{array}{l}\text { CLO } \\
\text { Diet B }\end{array}$ & $\begin{array}{l}\text { RWO } \\
\text { Diet C }\end{array}$ & $\begin{array}{l}\text { RWO-I } \\
\text { Diet D }\end{array}$ & $\begin{array}{l}\text { RWO-II } \\
\text { Diet E }\end{array}$ & $\begin{array}{l}\text { CWO } \\
\text { Diet F }\end{array}$ \\
\hline TAG $(\mathrm{mmol} / \mathrm{l})$ & $2.18 \pm 0.52$ & $2.36 \pm 0.61$ & $2.35 \pm 0.68$ & $2.04 \pm 0.49$ & $2.03 \pm 0.75$ & $2.04 \pm 0.74$ \\
\hline Glucose $(\mathrm{mmol} / \mathrm{l})$ & $14.5 \pm 2.40$ & $12.4 \pm 1.84$ & $15.2 \pm 3.25$ & $13.2 \pm 3.87$ & $13.6 \pm 2.56$ & $13.8 \pm 2.22$ \\
\hline Uric acid (mmol/l) & $409 \pm 165$ & $399 \pm 168$ & $541 \pm 211$ & $505 \pm 250$ & $414 \pm 219$ & $354.4 \pm 132$ \\
\hline Proteins (g/l) & $83.1 \pm 18.2$ & $73.3 \pm 13.5$ & $87.7 \pm 16.4$ & $85.1 \pm 21.6$ & $81.9 \pm 16.7$ & $79.3 \pm 11.8$ \\
\hline NEFA (mmol/l) & $1.44 \pm 0.24$ & $1.66 \pm 0.19$ & $1.64 \pm 0.25$ & $1.56 \pm 0.29$ & $1.56 \pm 0.34$ & $1.78 \pm 0.60$ \\
\hline Spleen (g) & $0.17 \pm 0.05$ & $0.17 \pm 0.02$ & $0.21 \pm 0.07$ & $0.20 \pm 0.07$ & $0.19 \pm 0.05$ & $0.17 \pm 0.03$ \\
\hline Kidney (g) & $0.16 \pm 0.03$ & $0.15 \pm 0.01$ & $0.16 \pm 0.02$ & $0.16 \pm 0.03$ & $0.15 \pm 0.02$ & $0.15 \pm 0.03$ \\
\hline Heart (g) & $0.15 \pm 0.02$ & $0.13 \pm 0.01$ & $0.15 \pm 0.02$ & $0.14 \pm 0.02$ & $0.14 \pm 0.02$ & $0.13 \pm 0.01$ \\
\hline Adipose (g) & $2.24 \pm 0.67$ & $1.60 \pm 0.58$ & $2.03 \pm 0.74$ & $1.71 \pm 0.67$ & $2.08 \pm 0.80$ & $1.44 \pm 0.38$ \\
\hline IFNy (pg/ml) & $0.79 \pm 0.97$ & $1.26 \pm 1.90$ & $0.43 \pm 0.14$ & $0.57 \pm 0.42$ & $0.60 \pm 0.51$ & $0.45 \pm 0.19$ \\
\hline IL-10 (pg/ml) & $40.7 \pm 6.64$ & $40.4 \pm 17.1$ & $40.4 \pm 12.6$ & $62.8 \pm 88.6$ & $39.1 \pm 9.66$ & $39.4 \pm 10.5$ \\
\hline IL-1 $\beta(p g / m l)$ & $2.81 \pm 1.49$ & $2.61 \pm 0.92$ & $1.41 \pm 2.68$ & $3.29 \pm 1.92$ & $2.57 \pm 2.09$ & $3.20 \pm 1.36$ \\
\hline IL-2 (pg/ml) & $1.03 \pm 0.33$ & $0.94 \pm 0.40$ & $1.13 \pm 0.40$ & $1.09 \pm 0.61$ & $1.15 \pm 0.44$ & $1.17 \pm 0.27$ \\
\hline IL-5 (pg/ml) & $10.9 \pm 5.54$ & $7.82 \pm 3.60$ & $9.20 \pm 4.83$ & $9.28 \pm 4.97$ & $7.33 \pm 3.19$ & $10.2 \pm 3.93$ \\
\hline IL-6 (pg/ml) & $61.1 \pm 64.3$ & $43.4 \pm 28.1$ & $50.6 \pm 24.4$ & $73.1 \pm 55.5$ & $58.4 \pm 52.1$ & $46.5 \pm 28.5$ \\
\hline $\mathrm{KC} / \mathrm{GRO}(\mathrm{pg} / \mathrm{ml})$ & $195 \pm 52.9$ & $172 \pm 43.5$ & $168 \pm 52.3$ & $173 \pm 81.2$ & $146 \pm 32.7$ & $156 \pm 63.1$ \\
\hline TNFa (pg/ml) & $25.3 \pm 13.4$ & $21.6 \pm 5.90$ & $20.1 \pm 5.66$ & $21.6 \pm 10.3$ & $24.6 \pm 7.11$ & $19.11 \pm 4.80$ \\
\hline
\end{tabular}

Data are presented as mean \pm SD. CO $(n=11)$, CLO $(n=9)$, RWO $(n=11)$, RWO-I $(n=11)$, RWO-II $(n=12)$, CWO $(n=10)$. None of the values for any group in this table are significantly different from values in any other group

This study indicates that a physiologically obtainable dietary supplementation with CWO prevents WDinduced atherogenesis. Mice fed a diet supplemented with $1 \%$ CWO for 13 weeks had significantly lower development of atherosclerotic lesions in the aortic arch compared to mice fed WD supplemented with $1 \%$ CO. There was, however, no differences in lesion formation in less lesion-prone parts of the aorta, such as the thoracic aorta, abdominal aorta or the total aorta. It was also evident that serum levels of LDL/VLDL-cholesterol and ox-LDLcholesterol were markedly reduced, whereas serum TAS was significantly enhanced in CWO-fed mice compared to mice fed $\mathrm{CO}$ or CLO. This is in accordance with our recent demonstration that extracts from whale blubber have in vitro antioxidative effects [25]. A similar antiatherosclerotic effect has previously been reported in $\mathrm{ApoE}^{-1-}$-mice fed seal oil [27]. It is, however, worthy to note that the seal oil was given in combination with extra virgin olive oil known to contain protective antioxidants. Antioxidants prevent lipid peroxidation and oxidative damage [30]. Indeed, the results herein suggest that CWO does not need a further addition of antioxidants, something which was shown by the high antioxidative capacity observed in our in vitro study [25]. Together, the increased TAS levels and lower ox-LDL-cholesterol levels explain the observed reduction of atherosclerotic lesions in the aortic arch observed in the CWO-fed mice. In addition, the final body weights were lower in the CWO- fed mice even though the feed intake was equal. At the same time, no differences in serum TAS levels or final body weights were observed between the CLO- and the CO-fed mice.

Although cholesterol is crucial for all mammalian cells, it is well known that increased circulating levels of LDL-cholesterol is a major risk factor for atherosclerotic CVD. In recent years much effort has been put into reducing circulation cholesterol levels in high-risk patients [31]. The liver is the major site for cholesterol synthesis, and de novo homeostasis is regulated by intestinal absorption and faecal and biliary excretion [32]. To shed light on the mechanisms involved in the observed LDL/ VLDL-lowering effect of CWO, several receptors and enzymes involved in the cholesterol metabolism were investigated by means of gene expression analysis. In our study, expression of the hepatic genes $A b c g 5, A b c g 8$ ( $p=$ 0.064), Sr-b1 and Ppara were moderately up-regulated in mice fed CWO compared to mice fed CO. All these genes encode for proteins that are important for cholesterol homeostasis. The liver receptor SR-B1 is involved in the selective uptake of cholesteryl esters (CE) from high density lipoproteins (HDL) both in humans and mice [33]. The hepatic expression of $S r-b 1$ has been shown to play an atheroprotective role associated with its impact on circulation cholesterol levels [34]. CE is further converted into bile by the obligate heterodimer ABCG5 and ABCG8 located in the hepatocytes [35]. 


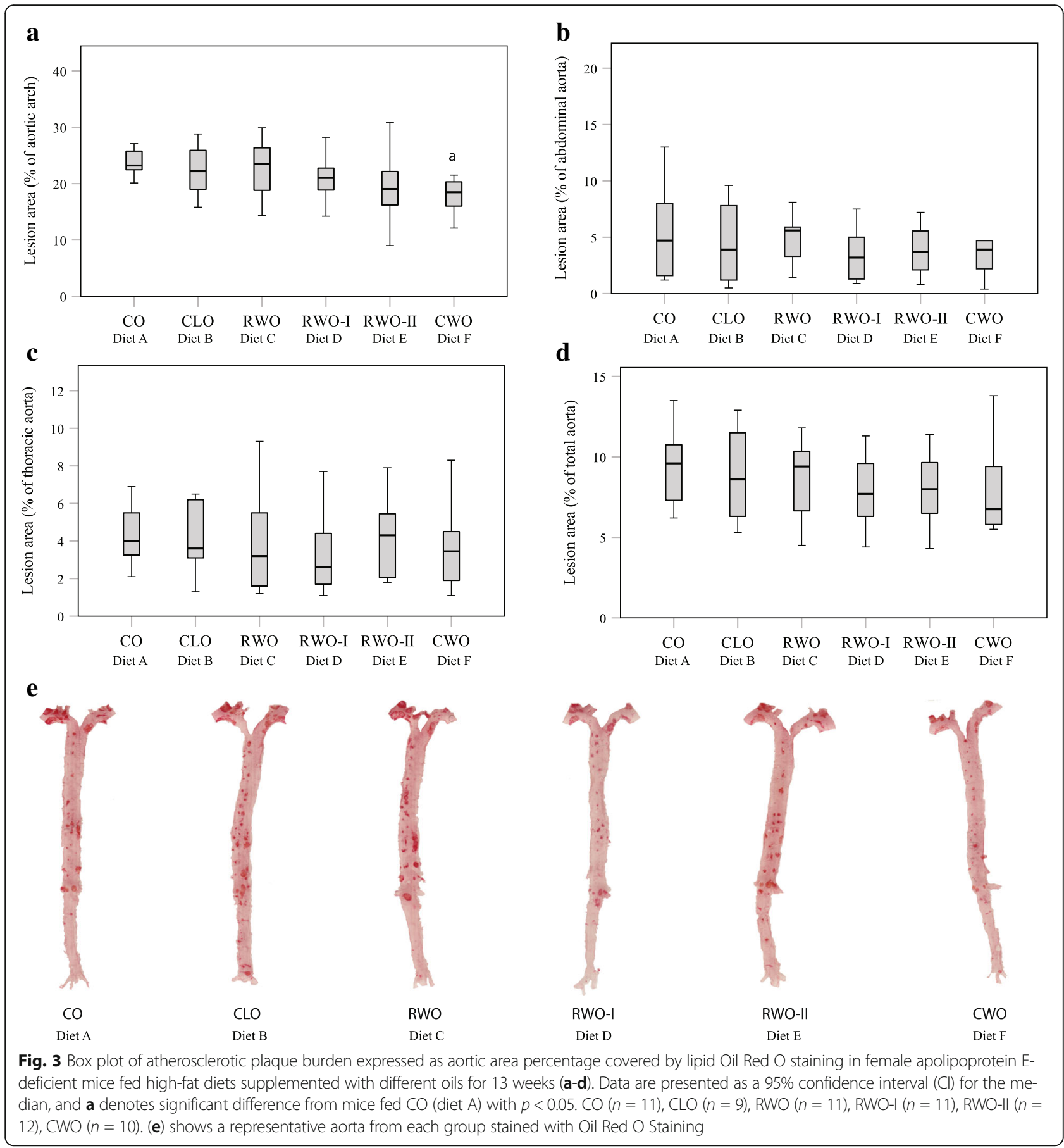

Overexpression of $A b c g 5 / A b c g 8$ has been shown to increase biliary cholesterol excretion, together with reduced levels of liver inflammatory markers [36]. This effect was lower in mice fed CLO as only expression of $A b c g 8$ and $S r-b 1$ were increased compared to the COcontrol mice. This corresponds well with the increased expression of $A b c g 5$ together with reduced circulating levels of both LDL/VLDL-cholesterol and ox-LDLcholesterol observed in CWO-fed mice. At the same time, these mice displayed no changes in inflammatory markers as assessed by hepatic gene expression and serum protein levels. PPAR $\alpha$ is a nuclear receptor involved in transport, uptake, oxidation and reduction of FA and the triglyceride synthesis [37], and may also be involved in the observed effects. Natural ligands for PPAR $\alpha$ include n3-PUFA and it is possible that the diets containing the marine oils may activate PPAR $\alpha$ and contribute to the beneficial effects observed in this study. 


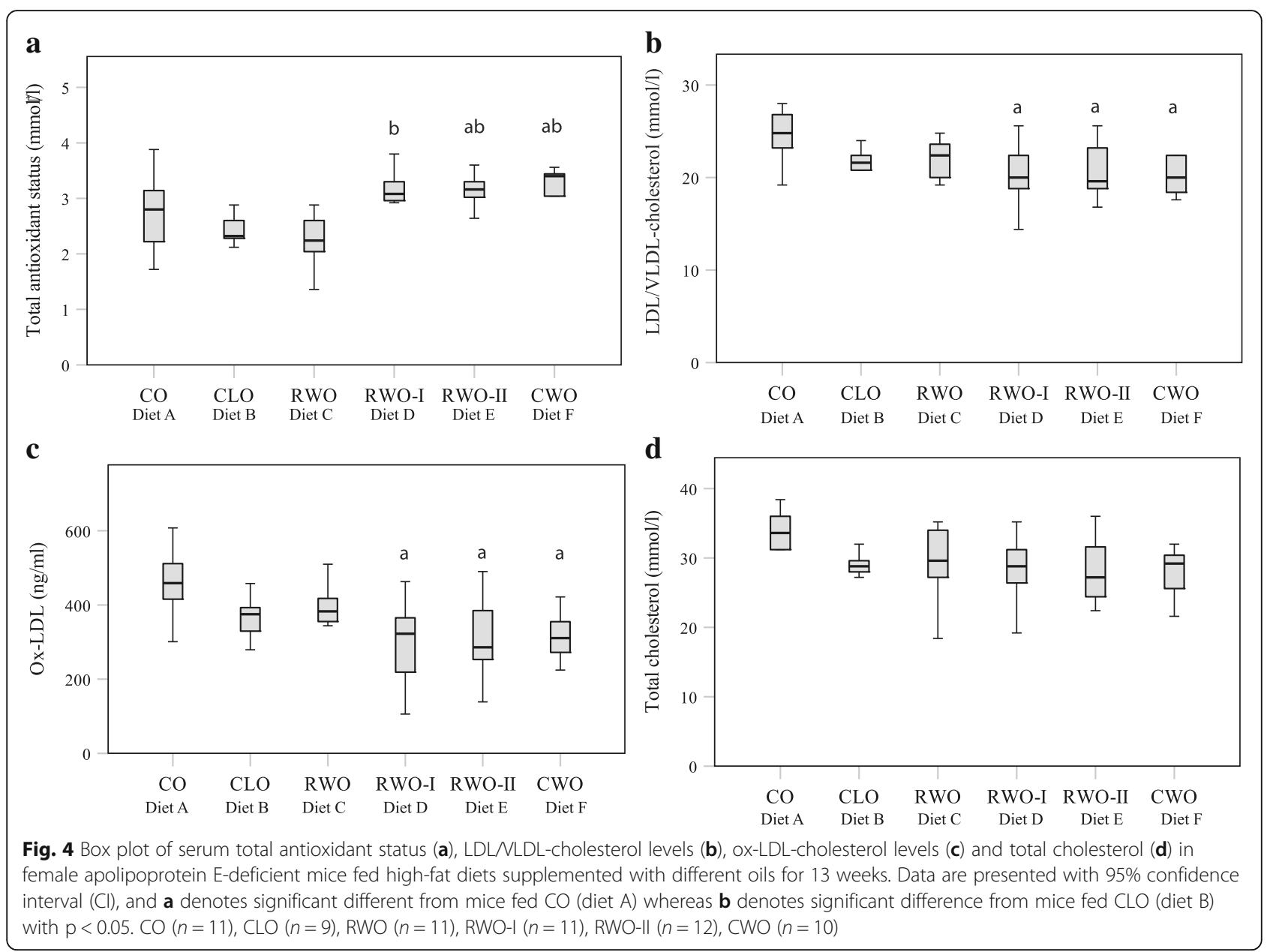

We were further interested in whether the beneficial effects from CWO might be obtained via reconstitution of the extract(s) with RWO. Hence, two different extracts were prepared and reconstituted with RWO and the mice received three addition diets supplemented with (i) RWO (diet C), (ii) RWO + extract I (RWO-I, diet D) and (iii) RWO + extract II (RWO-II, diet E). This would indicate whether the anti-inflammatory activity was associated with the fatty acids (RWO), the watersoluble components in the whale oil (RWO-I) or the water-soluble components in the residual whale blubber (RWO-II). Indeed, compared to corn oil both RWO-I and RWO-II also reduced serum LDL/VLDL-cholesterol and ox-LDL-cholesterol concentration, whereas serum total antioxidant status was increased. Mice fed RWO-I had increased hepatic expression of $A b c g 8, S r-b 1$ and Ppara, and mice fed RWO-II had even more affected genes as the hepatic expression of Abcg5, Abcg8, Cyp $7 a l$, Hmgcr, Sr-b1, Ppara and Ppary, were all increased. The mice fed RWO-II also had increased expression of Cyp7al, Vldlr and Ppary compared to the CLO-fed mice. However, no changes were observed for atherosclerosis (not significantly reduced) or inflammation markers. This indicated that the extracts affected the same metabolic processes, however, the phenotypic effects were moderate compared to the effects observed in CWOfed mice.

Due to the lower content of EPA and DHA in whale blubber compared to fish oils, we expected, and observed, unaltered serum TAG levels. Unaltered serum TAG levels have been observed in several other studies where $\mathrm{ApoE}^{-1}$ - -mice were given comparable amounts of EPA, DPA and DHA [38-40]. Efficient reduction of serum TAG levels requires EPA, DPA and DHA supplementation in pharmaceutical doses which may be difficult to obtain through diet [41]. Whale blubber oil is known to contain large amounts of DPA compared to fish oil, and some studies have indicated that DPA may be the most important LC n3-PUFA when it comes to protection of CVD $[42,43]$. Taken together these findings may imply that dietary CWO promotes cholesterol clearance from the circulation, increased clearance of cholesterol in the liver elevated TAS levels, lowered oxidation of LDLcholesterol, all conducting to mitigate atherosclerosis. 
Table 3 Hepatic gene expression in female apolipoprotein E-deficient mice fed high-fat Western-type diets supplemented with different oils for 13 weeks

\begin{tabular}{|c|c|c|c|c|c|}
\hline a) & $\begin{array}{l}\text { CLO } \\
\text { Diet B [95\% Cl] }\end{array}$ & $\begin{array}{l}\text { RWO } \\
\text { Diet C [95\% Cl] }\end{array}$ & $\begin{array}{l}\text { RWO-I } \\
\text { Diet D [95\% Cl] }\end{array}$ & $\begin{array}{l}\text { RWO-II } \\
\text { Diet E [95\% Cl] }\end{array}$ & $\begin{array}{l}\text { CWO } \\
\text { Diet F [95\% Cl] }\end{array}$ \\
\hline Tnfa & $1.03[0.24-2.59]$ & $0.76[0.16-2.35]$ & $0.79[0.11-5.21]$ & $0.76[0.14-2.38]$ & 1.18 [0.16-13.9] \\
\hline Mcp 1 & $1.01[0.37-2.70]$ & 0.94 [0.35-2.59] & $0.79[0.11-3.15]$ & $0.80[0.26-2.78]$ & $0.92[0.23-3.27]$ \\
\hline $11-6$ & $1.39[0.42-5.14]$ & $0.87[0.26-2.52]$ & $1.09[0.26-3.07]$ & $1.18[0.29-4.20]$ & $0.79[0.11-4.22]$ \\
\hline Icaml & $1.11[0.70-1.704]$ & $1.08[0.65-0.21]$ & $1.09[0.462-2.46]$ & $0.74[0.02-1.87]$ & $1.18[0.52-2.25]$ \\
\hline Vcam1 & $0.85[0.47-1.38]$ & $0.86[0.55-1.31]$ & $0.88[0.57-1.40]$ & $0.89[0.50-1.29]$ & $0.85^{*}[0.50-1.39]$ \\
\hline Pon2 & $0.96[0.76-1.22]$ & $0.99[0.76-1.29]$ & 0.98 [0.83-1.33] & $0.96[0.81-1.12]$ & $1.00[0.73-1.25]$ \\
\hline $\mathrm{Nfe} 212$ & $0.98[0.62-1.47]$ & $1.01[0.64-2.04]$ & $0.93[0.57-1.52]$ & $1.01[0.65-1.48]$ & $1.06[0.61-1.76]$ \\
\hline Upc2 & $0.96[0.43-1.50]$ & $1.03[0.49-1.58]$ & $1.03[0.36-2.33]$ & $1.11[0.45-2.01]$ & $1.35[0.49-3.02]$ \\
\hline$A b c g 5$ & $1.15[0.45-1.90]$ & $1.06[0.40-1.71]$ & $1.08[0.31-2.42]$ & $1.28^{*}[0.51-2.22]$ & $1.46^{*}[0.59-2.58]$ \\
\hline Abcg8 & $1.32^{*}[0.64-2.61]$ & $1.12[0.56-2.16]$ & $1.43^{*}[0.67-2.05]$ & $1.40^{*}[0.65-2.66]$ & $1.31[0.62-2.83]$ \\
\hline Acat2 & $1.00[0.64-1-66]$ & $1.02[0.50-2.22]$ & $1.02[0.57-1.83]$ & $1.09[0.48-2.30]$ & $0.91[0.50-1.52]$ \\
\hline Cyp7a1 & $0.88[0.11-4.85]$ & $1.19[0.34-4.47]$ & $1.48[0.23-7.65]$ & $1.95^{*}[0.35-8.92]$ & $1.19[0.37-6.34]$ \\
\hline $\mathrm{HmgCr}$ & 1.16 [0.62-2.12] & $1.11[0.60-2.22]$ & $1.12[0.55-2.38]$ & $1.31^{*}[0.62-2.67]$ & $1.04[0.49-2.40]$ \\
\hline Ldlr & $1.13[0.57-2.55]$ & 1.14 [0.61-2.09] & $1.27[0.57-2.67]$ & $1.19[0.61-2.38]$ & $1.03[0.40-2.55]$ \\
\hline$S r-b 1$ & $1.29^{*}[0.76-2.29]$ & $1.23[0.67-2.30]$ & $1.43^{*}[0.78-2.46]$ & $1.26^{*}[0.58-2.25]$ & $1.29^{*}[0.66-2.27]$ \\
\hline VIdlr & $0.75^{*}[0.34-1.59]$ & $0.92[0.46-1.75]$ & 0.87 [0.23-2.05] & $1.14[0.58-2.11]$ & 0.79 [0.30-1.61] \\
\hline Ppara & $1.14[0.53-2.22]$ & $1.41^{*}[0.67-2.66]$ & $1.79^{*}[0.77-3.81]$ & $1.39^{*}[0.74-2.77]$ & $1.39^{*}[0.60-3.09]$ \\
\hline Ppary & 0.92 [0.54-1.39] & $1.15[0.67-1.71]$ & $1.16[0.52-2.21]$ & $1.26^{*}[0.70-2.01]$ & 1.12 [0.47-9.86] \\
\hline Fasn & $1.21[0.35-5.39]$ & $1.01[0.20-4.31]$ & $0.72[0.22-3.60]$ & $0.94[0.21-4.88]$ & $0.81[0.20-3.74]$ \\
\hline b) & $\begin{array}{l}\text { CO } \\
\text { Diet A [95\% Cl] }\end{array}$ & $\begin{array}{l}\text { RWO } \\
\text { Diet C [95\% Cl] }\end{array}$ & $\begin{array}{l}\text { RWO-I } \\
\text { Diet D [95\% CI] }\end{array}$ & $\begin{array}{l}\text { RWO-II } \\
\text { Diet E [95\% Cl] }\end{array}$ & $\begin{array}{l}\text { CWO } \\
\text { Diet F [95\% Cl] }\end{array}$ \\
\hline Tnfa & $0.97[0.39-4.10]$ & $0.74[0.36-1.69]$ & $0.77[0.15-4.35]$ & 0.74 [0.29-1.69] & $1.15[0.25-11.0]$ \\
\hline Mcp 1 & $0.99[0.37-2.70]$ & $0.93[0.44-2.15]$ & 0.78 [0.09-3.45] & $0.79[0.27-2.29]$ & $0.92[0.22-2.73]$ \\
\hline $11-6$ & $0.72[0.20-2.43]$ & $0.63[0.15-2.25]$ & $0.79[0.16-2.62]$ & $0.85[0.16-3.70]$ & $0.51^{*}[0.07-3.67]$ \\
\hline Icaml & $0.90[0.59-1.44]$ & 0.98 [0.69-1.90] & $0.98[0.42-2.25]$ & 0.67 [0.02-1.59] & $1.06[0.45-1.89]$ \\
\hline Vcam1 & $1.18[0.72-2.14]$ & $1.01[0.57-2.01]$ & $1.03[0.57-1.98]$ & 1.05 [0.50-1.98] & 1.00 [0.51-2.09] \\
\hline Pon2 & $1.05[0.82-1.32]$ & $1.04[0.77-1.39]$ & 1.02 [0.79-1.39] & $1.00[0.78-1.26]$ & $1.05[0.77-1.39]$ \\
\hline Nfe212 & $1.03[0.68-1.62]$ & $1.04[0.74-2.14]$ & $0.95[0.55-1.45]$ & $1.03[0.73-1.40]$ & $1.09[0.70-1.75]$ \\
\hline Upc2 & $1.04[0.67-2.35]$ & $1.07[0.71-1.54]$ & 1.07 [0.59-2.14] & 1.15 [0.63-1.98] & $1.41^{*}[0.69-2.94]$ \\
\hline Abcg 5 & $0.87[0.53-2.21]$ & $0.93[0.57-1.47]$ & $0.94[0.24-2.07]$ & $1.12[0.64-1.89]$ & $1.27[0.63-2.22]$ \\
\hline Abcg8 & $0.76^{*}[0.38-1.58]$ & $0.85[0.46-1.71]$ & $1.09[0.58-2.14]$ & $1.06[0.53-2.06]$ & $0.99[0.51-2.14]$ \\
\hline Acat2 & 0.99 [0.60-1.55] & $1.01[0.48-2.13]$ & $1.01[0.56-1.94]$ & $1.09[0.45-2.46]$ & 0.91 [0.49-1.55] \\
\hline Cyp7a1 & $1.14[0.21-8.90]$ & $1.36[0.35-9.16]$ & $1.69[0.23-14.4]$ & $2.23^{*}[0.35-17.1]$ & $1.36[0.37-10.5]$ \\
\hline $\mathrm{Hmgcr}$ & $0.86[0.47-1.62]$ & $0.96[0.62-1.63]$ & $0.97[0.58-1.72]$ & $1.13[0.60-2.18]$ & $0.90[0.50-2.00]$ \\
\hline Ldlr & $0.89[0.39-1.76]$ & $1.01[0.49-1.78]$ & $1.12[0.30-2.77]$ & 1.05 [0.49-1.98] & 0.91 [0.36-2.09] \\
\hline$S r-b 1$ & $0.77^{*}[0.44-1.32]$ & $0.95[0.54-1.61]$ & $1.10[0.65-1.74]$ & $0.97[0.49-1.57]$ & $0.99[0.54-1.59]$ \\
\hline VIdlr & $1.34^{*}[0.63-2.99]$ & $1.23[0.62-2.37]$ & $1.17[0.30-2.77]$ & $1.52^{*}[0.76-2.97]$ & $1.05[0.39-2.46]$ \\
\hline Ppara & $0.88[0.45-1.89]$ & $1.23[0.53-2.24]$ & $1.57^{*}[0.77-3.30]$ & $1.21[0.76-2.97]$ & $1.22[0.61-2.91]$ \\
\hline Ppary & $1.09[0.72-1.84]$ & $1.25^{*}[0.80-1.83]$ & $1.26[0.56-2.27]$ & $1.37^{*}[0.87-2.06]$ & $1.22[0.59-10.6]$ \\
\hline Fasn & $0.83[0.19-2.85]$ & $0.84[0.14-2.99]$ & $0.59^{*}[0.19-2.66]$ & $0.78[0.18-3.34]$ & $0.66[0.15-1.27]$ \\
\hline
\end{tabular}

Relative comparison of mice fed CO to the other diets group (a), and relative comparison of mice fed CLO to the other diets group (b). 95\% confidence interval [95\% Cl]. The relative gene expression was analysed with REST 2009 and *denotes significant difference $(p<0.05)$. CO $(n=11)$, CLO $(n=9)$, RWO $(n=11)$, RWO-I $(n=11)$, RWO-II $(n=12)$, CWO $(n=10)$ 


\section{Conclusion}

In the present study, we observed that mice fed WD with $1 \%$ CWO had reduced formation of atherosclerotic lesions in the aortic arch compared to mice fed WD with $1 \% \mathrm{CO}$. In addition, CWO-fed mice had reduced serum LDL/VLDLcholesterol, ox-LDL-cholesterol and body weight and increased serum total antioxidant status compared to CO-fed mice. Our study adds novel insight into the putative protective mechanisms of dietary CWO supplementation in CVD, including activation of endogenous antioxidant responses, inhibition of LDL oxidation, attenuation of the diet-induced hypercholesterolemia and reduced aortic atherogenesis. These results may inform future dietary recommendations to reduce CVD and promote public health.

\section{Additional file}

Additional file 1: Table S1. Predesigned TaqMan ${ }^{\oplus}$ Gene Expression assays " Reference genes used to normalize the results. (DOCX 14 kb)

\begin{abstract}
Abbreviations
ABCG5: ATP binding cassette, sub-family G member 5; ABCG8: ATP binding cassette, sub-family G member 8; ACAT2: Acetyl-Coenzyme A acetyltransferase 2; ppoE $^{-/-}$: Apolipoprotein E-deficient; CE: Cholesteryl esters; Cl: Confidence interval; CLO: Cod liver oil; CO: Corn oil; CVD: Cardiovascular disease; CWO: Cold pressed whale oil; CYP7A1: Cytochrome P450 7A1; DHA: Docosahexaenoic acid; DPA: Docosapentaenoic acids; EPA: Eicosapentaenoic acid; FA: Fatty acids; FASN: Fatty acid synthase; HDL: High density lipoproteins; HMGCR: 3-hydroxy-3methyl-glutaryl-Coenzyme A reductase; HPRT1: Hypoxanthine-guanine phosphoribosyltransferase 1; ICAM1: Intercellular adhesion molecule 1; IFNץ: Interferon gamma; IL-10: Interleukin 10; IL-1ß: Interleukin 1 beta; IL2: Interleukin 2; IL-5: Interleukin 5; IL-6: Interleukin 6; KC-GRO: Keratinocyte chemoattractant growth-regulated oncogene; LC n3-PUFA: Long chain n3polyunsaturated fatty acid; LDL: Low density lipoprotein; LDLR: LDL-receptor; MCP-1: Monocyte chemotactic protein 1; n3-PUFA: n3-polyunsaturated fatty acid; NEFA: Non-esterified fatty acids; NFE212: Nuclear factor erythroid 2-related factor; Ox-LDL: Oxidized low density lipoprotein; PON2: Paroxynase 2; PPARa: Peroxisome proliferator-activated receptor- $a$; PPARY: Peroxisome proliferator-activated receptor- $\gamma$; PUFA: Polyunsaturated fatty acid; RWO: Refined whale oil; RWO-I: Refined whale oil + extract I; RWO-II: Refined whale oil + extract II; SR-B1: Scavenger receptor class B member 1; TAG: Triacylglycerol; TAS: Serum total antioxidant status; TBP: TATA-Box Binding Protein; TNFa: Tumour necrosis factor alpha; UCP2: Uncoupling protein 2; VCAM1: Vascular adhesion molecule 1; VLDL: Very low density lipoprotein; VLDLR: Very low density lipoprotein receptor; WD: Western type diet
\end{abstract}

\section{Acknowledgments}

Jan Ole Olsen, UiT - The Arctic University of Norway, is acknowledged for his skilful technical assistance. Nina Løvhaug, Ragnhild Osnes Hansen, Remi Osnes, Carina Sørensen and ass. Prof. Siri K. Knudsen at the Department of Comparative Medicine, UiT - The Arctic University of Norway, were responsible for daily caretaking of the mice. The publication charges for this article have been funded by a grant from the publication fund of UiT - The Arctic University of Norway.

\section{Funding}

The present work was supported by grants from funded by UiT - The Arctic University of Norway and from the Marine Biotechnology in Tromsø (MABIT) research program (Project UB0046; BlueOcean and UiT - The Arctic University of Norway).

\section{Authors' contributions}

$K E E, B \varnothing, E O E$ and SKS conceived and designed the study, MJW, KEE and SKS performed the experiments. MJW and KEE analyzed the data, and MJW and KEE wrote the paper. All authors contributed to the finalization of the manuscript. All authors read and approved the final manuscript.

\section{Ethics approval and consent to participate}

The Norwegian Animal Research Authority approved the study (approval number 3828). All experiments were performed following Federation for Laboratory Animal Science Association recommendations and according to the Norwegian legislation on the care and use of experimental animals.

\section{Competing interests}

The authors declare no competing interests, neither financial nor non-financial.

\section{Publisher's Note}

Springer Nature remains neutral with regard to jurisdictional claims in published maps and institutional affiliations.

\section{Author details}

${ }^{1}$ Norwegian College of Fishery Science, Faculty of Biosciences, Fisheries and Economics, UiT - The Arctic University of Norway, 9037 Tromsø, Norway. ${ }^{2}$ Nofima, Muninbakken 9-13, pb 6122, 9291 Tromsø, Norway. ${ }^{3}$ Faculty of Health Science, IMB, K.G Jebsen TREC, UiT - The Arctic University of Norway, 9037 Tromsø, Norway.

Received: 8 January 2018 Accepted: 17 April 2018

Published online: 04 May 2018

\section{References}

1. Boudoulas KD, et al. Coronary atherosclerosis: pathophysiologic basis for diagnosis and management. Prog Cardiovasc Dis. 2016;58(6):676-92.

2. Libby P, Ridker PM, Hansson GK. Progress and challenges in translating the biology of atherosclerosis. Nature. 2011;473(7347):317-25.

3. Khan $\mathrm{R}$, et al. Novel anti-inflammatory therapies for the treatment of atherosclerosis. Atherosclerosis. 2015;240(2):497-509.

4. Ross R. Atherosclerosis - an inflammatory disease. N Engl J Med. 1999; 340(2):115-26.

5. Tabas I, García-Cardeña G, Owens GK. Recent insights into the cellular biology of atherosclerosis. J Cell Biol. 2015;209(1):13-22.

6. Stoll G, Bendszus M. Inflammation and atherosclerosis. Novel insights into plaque formation and destabilization. Stroke. 2006;37(7):1923-32.

7. Libby P, Ridker PM, Hansson GK. Inflammation in atherosclerosis: from pathophysiology to practice. J Am Coll Cardiol. 2009;54(23):2129-38.

8. Ait-Oufella $\mathrm{H}$, et al. Recent advances on the role of cytokines in atherosclerosis. Arterioscler Thromb Vasc Biol. 2011;31(5):969-79.

9. Deshmane SL, et al. Monocyte chemoattractant Protein-1 (MCP-1): an overview. J Interf Cytokine Res. 2009;29(6):313-26.

10. McKellar GE, et al. Role for TNF in atherosclerosis? Lessons from autoimmune disease. Nat Rev Cardiol. 2009;6(6):410-7.

11. Qamar A, Rader DJ. Effect of interleukin $1 \beta$ inhibition in cardiovascular disease. Curr Opin Lipidol. 2012;23(6):548-53.

12. Kromhout D, de Goede J. Update on cardiometabolic health effects of $\omega-3$ fatty acids. Curr Opin Lipidol. 2014;25(1):85-90.

13. Mori TA. Omega-3 fatty acids and cardiovascular disease: epidemiology and effects on cardiometabolic risk factors. Food Funct. 2014;5(9):2004-19.

14. Nicholson T, Khademi H, Moghadasian MH. The role of marine $n-3$ fatty acids in improving cardiovascular health: a review. Food Funct. 2013;4(3):357-65.

15. Fetterman JW Jr. And M.M. Zdanowicz, Therapeutic potential of n-3 polyunsaturated fatty acids in disease. Am J Health Syst Pharm. 2009;66(13):1169-79.

16. Siriwardhana N, Kalupahana NS, Moustaid-Moussa N. Health benefits of n-3 polyunsaturated fatty acids: eicosapentaenoic acid and docosahexaenoic acid. Adv Food Nutr Res. 2012;65:211-22.

17. Maehre. H.K., et al., omega-3 Fatty Acids and Cardiovascular Diseases: Effects, Mechanisms and Dietary Relevance. Int J Mol Sci. 2015;16(9):22636-61.

18. Jensen IJ, Maehre HK. Preclinical and clinical studies on antioxidative, antihypertensive and cardioprotective effect of marine proteins and peptides-A Review. Marine Drugs. 2016;14(11):211.

19. Larsen R, Eilertsen KE, Elvevoll EO. Health benefits of marine foods and ingredients. Biotechnol Adv. 2011;29(5):508-18.

20. Micha $R$, et al. Association between dietary factors and mortality from heart disease, stroke, and type 2 diabetes in the United States. JAMA. 2017;317(9):912-24.

21. Skaug HJ, H G, Haug T, Lindstrøm U, Nilssen KT. Do minke whales Balaenoptera acutorostrata exhibit particular prey preferences? J Northw Atl Fish Sci. 1997;22:91-104. 
22. Strandberg U, et al. Stratification, composition, and function of marine mammal blubber: the ecology of fatty acids in marine mammals. Physio Biochem Zool. 2008;81(4):473-85.

23. Osterud B, et al. Effect of marine oils supplementation on coagulation and cellular activation in whole-blood. Lipids. 1995;30:1111-8.

24. Vognild $\mathrm{E}$, et al. Effects of dietary marine oils and olive oil on fatty acid composition, platelet membrane fluidity, platelet responses, and serum lipids in healthy humans. Lipids. 1998;33(4):427-36.

25. Walquist MJ, et al. Antioxidant and anti-inflammatory activities in extracts from Minke whale (Balaenoptera acutorostrata) blubber. Mediat Inflamm. 2017:2017:3835851.

26. Orkla-Health. Möller's. 2016. [cited 2017 09-27]; Available from: http://www. mollersomega3.com/.

27. Eilertsen $\mathrm{K}-\mathrm{E}$, et al. Dietary enrichment of apolipoprotein E-deficient mice with extra virgin olive oil in combination with seal oil inhibits atherogenesis. Lipids Health Dis. 2011;10(1):41.

28. ImageJ. Image processing and analysis in java. 2014. [cited 2017 12-20]; Available from: https://imagej.net/Welcome.

29. Pfaffl MW, Horgan GW, Dempfle L. Relative expression software tool (RESTO) for group-wise comparison and statistical analysis of relative expression results in real-time PCR. Nucleic Acids Res. 2002;30(9):e36.

30. Chen $Q$, et al. Reactive oxygen species: key regulators in vascular health and diseases. Br J Pharmacol. 2018;175(8):1279-92

31. Stone NJ, et al. 2013 ACC/AHA guideline on the treatment of blood cholesterol to reduce atherosclerotic cardiovascular risk in adults: a report of the American College of Cardiology/American Heart Association task force on practice guidelines. J Am Coll Cardiol. 2014;63(25 Pt B):2889-934.

32. Yu X-H, et al. ABCG5/ABCG8 in cholesterol excretion and atherosclerosis. Clin Chim Acta. 2014;428(Supplement C):82-8.

33. Linton MF, et al. SR-Bl: a multifunctional receptor in cholesterol homeostasis and atherosclerosis. Trends Endocrinol Metab. 2017;28(6):461-72.

34. Huby T, et al. Knockdown expression and hepatic deficiency reveal an atheroprotective role for SR-BI in liver and peripheral tissues. J Clin Invest. 2006;116(10):2767-76.

35. Brown JM, Yu L. Opposing gatekeepers of apical sterol transport: Niemann-pick C1-like 1 (NPC1L1) and ATP-binding cassette transporters G5 and G8 (ABCG5/ ABCG8). Immunol Endocr Metab Agents Med Chem. 2009:9(1):18-29.

36. Patel SB. Recent advances in understanding the STSL locus and ABCG5/ ABCG8 biology. Curr Opin Lipidol. 2014;25(3):169-75.

37. Abushouk Al, et al. Peroxisome proliferator-activated receptors as therapeutic targets for heart failure. Biomed Pharmacother. 2017;95:692-700.

38. Sun $\mathrm{R}$, et al. Dietary supplementation with fish oil alters the expression levels of proteins governing mitochondrial dynamics and prevents high-fat diet-induced endothelial dysfunction. Br J Nutr. 2014;112(2):145-53.

39. Yoshihara T, et al. Omega 3 polyunsaturated fatty acids suppress the development of aortic aneurysms through the inhibition of macrophagemediated inflammation. Circ J. 2015;79(7):1470-8.

40. Jensen IJ, et al. Dietary intake of cod and scallop reduces atherosclerotic burden in female apolipoprotein E-deficient mice fed a western-type high fat diet for 13 weeks. Nutr Metab (Lond). 2016;13:8.

41. Shearer GC, Savinova OV, Harris WS. Fish oil - how does it reduce plasma triglycerides? Biochim Biophys Acta. 2012;1821(5):843-51.

42. Leng GC, et al. Plasma essential fatty acids, cigarette smoking, and dietary antioxidants in peripheral arterial disease. A population-based case-control study. Aterioscler Thromb. 1994;14(3):471-8.

43. Del Gobbo $L C$, et al. $\Omega-3$ polyunsaturated fatty acid biomarkers and coronary heart disease: pooling project of 19 cohort studies. JAMA Intern Med. 2016;176(8):1155-66.

\section{Ready to submit your research? Choose BMC and benefit from:}

- fast, convenient online submission

- thorough peer review by experienced researchers in your field

- rapid publication on acceptance

- support for research data, including large and complex data types

- gold Open Access which fosters wider collaboration and increased citations

- maximum visibility for your research: over $100 \mathrm{M}$ website views per year

At BMC, research is always in progress.

Learn more biomedcentral.com/submissions 